\title{
Soil Nutrients, Landscape Age, and Sphagno-Eriophoretum vaginati Plant Communities in Arctic Moist-Acidic Tundra Landscapes
}

\author{
Joel A. Mercado-Díaz*, William A. Gould, Grizelle González \\ USDA Forest Service, International Institute of Tropical Forestry, Jardín Botánico Sur, 1201 Calle Ceiba, Río \\ Piedras, Puerto Rico \\ Email: ${ }^{*}$ joel pr19@hotmail.com
}

Received 16 September 2014; revised 14 October 2014; accepted 28 October 2014

Copyright (C) 2014 by authors and Scientific Research Publishing Inc.

This work is licensed under the Creative Commons Attribution International License (CC BY). http://creativecommons.org/licenses/by/4.0/

(c) (i) Open Access

\section{Abstract}

Most research exploring the relationship between soil chemistry and vegetation in Alaskan Arctic tundra landscapes has focused on describing differences in soil elemental concentrations (e.g. C, N and $P$ ) of areas with contrasting vegetation types or landscape age. In this work we assess the effect of landscape age on physico-chemical parameters in organic and mineral soils from two longterm research sites in northern Alaska, the Toolik Lake and Imnavait grids. These two sites have contrasting landscape age but similar vegetation composition. We also used correlation analysis to evaluate if differences in any of these parameters were linked with between-site variation in the abundance of growth forms. Our analysis was narrowed to soils in Sphagno-Eriophoretum vaginati plant communities. We found no significant differences between these sites for most parameters evaluated, except for total Ca which was significantly higher in organic soils from Imnavait vs. Toolik and total Na which was significantly higher in mineral horizons from Toolik compared to Imnavait. Moreover, the abundance of non-Sphagnum mosses was positively correlated with total Ca in organic soils, whereas the abundance of forbs, non-Sphagnum mosses and bryophytes was negatively correlated with total $\mathrm{Na}$ in mineral soils. We suggest that differences in the concentration of these two elements are most likely tied to landscape age differences between these sites. However, since observed dissimilarity in terms of total $\mathrm{Ca}$ in organic soils and total $\mathrm{Na}$ in mineral soils is concordant with correlation patterns observed between these elements and the aforementioned growth forms, it is likely that existing differences in vegetation composition between these sites are also influencing the concentration of these elements in soils, particularly that of Ca, since non-Sphagnum mosses are dominant above organic soils and are therefore expected to significantly influence biogeochemical processes at this horizon. Thus, we conclude that 
except for organic Ca and mineral $\mathrm{Na}$, there is little difference between these sites in terms of their soil physico-chemical properties. We suggest that most of the influence of landscape age on evaluated parameters is masked by factors such as moderate cryoturbation and similarities in terms of vegetation properties and climate. These observations are relevant as they suggest a linkage between soil chemistry and vegetation composition in this tundra region.

\section{Keywords}

\section{Arctic Alaska, Soil Nutrients, Moist-Acidic Tussock Tundra, Vegetation}

\section{Introduction}

Studies have shown that landscape age (time since deglaciation) is an important factor influencing essential biogeochemical processes in Arctic tundra soils [1]-[6]. For instance, Hobbie and Gough [7] compared foliar and soil nutrients between landscapes that were deglaciated $>50,000$ (moist-acidic tundra [MAT]) and less than 11,500 years ago (moist non-acidic tundra [MNT]) and found higher rates of net $\mathrm{N}$ mineralization, cation exchange capacity and exchangeable base cations in soils at the geologically older site. Contrasting landscape age has also been proposed as a potential factor explaining variation in litter decomposition rates [8] and the rate of processes like $\mathrm{C}$ and $\mathrm{N}$ cycling in tundra soils [9].

In the Alaskan Arctic, differences in landscape age are also intimately related to differences in soil acidity [2] [3]. A number of important biological attributes are influenced by gradients of soil $\mathrm{pH}$ in this region. For example, some studies have documented the relationship between contrasting vegetation types with a distinct $\mathrm{pH}$ boundary that separates MAT and MNT [7] [9]. Considerable variation in species and growth form dominance within some tussock tundra communities has been associated with variation in soil $\mathrm{pH}$ [10] [11]. Differences in soil $\mathrm{pH}$ can also affect specific plant community attributes like vascular-plant species richness [12]. More recently, Eskelinen et al. [13] proposed an indirect effect of soil $\mathrm{pH}$ on vegetation via the evolution of bacteriabased microbial communities in alkaline soils where the properties of forb-produced organic matter were possibly sustaining the prevalence of soil bacteria.

Vegetation can also influence important soil processes like nutrient cycling which regulate nutrient concentrations and the size of $\mathrm{C}$ and $\mathrm{N}$ pools in tundra soils [14]. Since vegetation effects on soils are thought to be primarily related to the accumulation of organic material and nutrients [15], variation in specific traits influenced by plant communities, such as litter chemistry, is believed to play an important role in some of these processes. For instance, altered litter quality resulting from changes in species composition is known to affect processes like soil $\mathrm{N}$ mineralization [16]. However, some evidence appears to indicate that other landscape-scale soil processes are less likely to be significantly affected by vegetation. For example, Hobbie and Gough [8] demonstrated that variation in plant species composition did not account for differences in litter decomposition between MAT and MNT.

The linkage between patterns in vegetation composition and soils in tundra landscapes has not been characterized thoroughly, although several studies have contributed significantly in this direction. Chu and Grogan [17] found that variation in total C and N, Dissolved Organic Carbon (DOC) and N (DON), mineral N and N mineralization potential in organic soils in Daring Lake, Canada has been directly related to differences in vegetation types. Likewise, Eskelinen et al. [13] observed that forb-rich non-acidic heaths were associated with low C:N and low soluble $\mathrm{N}$ :phenolics ratios in soils, whereas shrub-dominated acidic heaths were associated with high values of these ratios. Understanding the reciprocal relationship between vegetation and soil dynamics in Arctic tundra ecosystems is challenging mostly because vegetation is ultimately controlled by meso-topographic relationships (slope position and soil moisture), micro-scale disturbances and factors related to long-term landscape evolution [4] [18]. This suggests that plant communities exhibit considerable spatial variability along soil chemical gradients.

In this study we compare a number of soil physico-chemical parameters from organic and mineral horizons of two study sites in northern Alaska that differ in landscape age, i.e., time since deglaciation $55 \mathrm{k}$ and $125 \mathrm{k}$ years, but have similar vegetation composition [18]. These are long- term vegetation monitoring areas which have been 
intensively used since the late 1980s to study the effects of climate change on tundra vegetation [19]-[21]. Our analysis is focused on soils derived from areas dominated by Sphagno-Eriophoretum vaginati plant communities' sensu Walker et al. [18], the most ubiquitous plant community within these sites. Little information on soil chemistry has been published from soils within these long-term monitoring sites. Only recently the works of Whittinghill and Hobbie [5] [6] and Keller et al. [23] have shown that the two landscape ages represented by these two study sites are similar in terms of several soil chemical parameters. The present work aims to advance the understanding of soil processes in this region by including analyses on physico-chemical properties of both mineral and organic horizons and other aspects of soil chemistry that are not necessarily evaluated in detail by those studies.

We also assess between-site differences in the abundance of a number of growth forms and subsequently evaluate the relationship between those differences and the variation between sites in terms of particular physico-chemical parameters to make inferences regarding how vegetation composition may be affecting soil physico-chemical properties at these two sites, and vice versa. These observations will contribute to a better understanding on how vegetation composition, landscape age and soil chemistry are reciprocally linked in this region.

\section{Materials and Methods}

\subsection{Study Area}

This study was carried out in two $1 \mathrm{~km}^{2}$ research grids, Toolik Lake and Imnavait Creek, in the vicinity of the Toolik Lake Field Station, Alaska, located north of the Brooks Range in the Southern Foothills Physiographic Province of the Alaskan North Slope [24] [25] (Figure 1). The region is underlain by continuous permafrost which is $250-300 \mathrm{~m}$ thick [26]. Both grids are dominated by MAT vegetation; however their landscapes are slightly different due primarily to differences in glacial age [18] [27] [28]. The Imnavait grid is in the headwaters of the Imnavait Creek, a small beaded tributary of the Kuparuk River basin [18]. This site lies on the Sagavanirktok (Middle Pleistocene) glacial drift which deglaciated about 125,000 years ago [27] [28]. Topography is

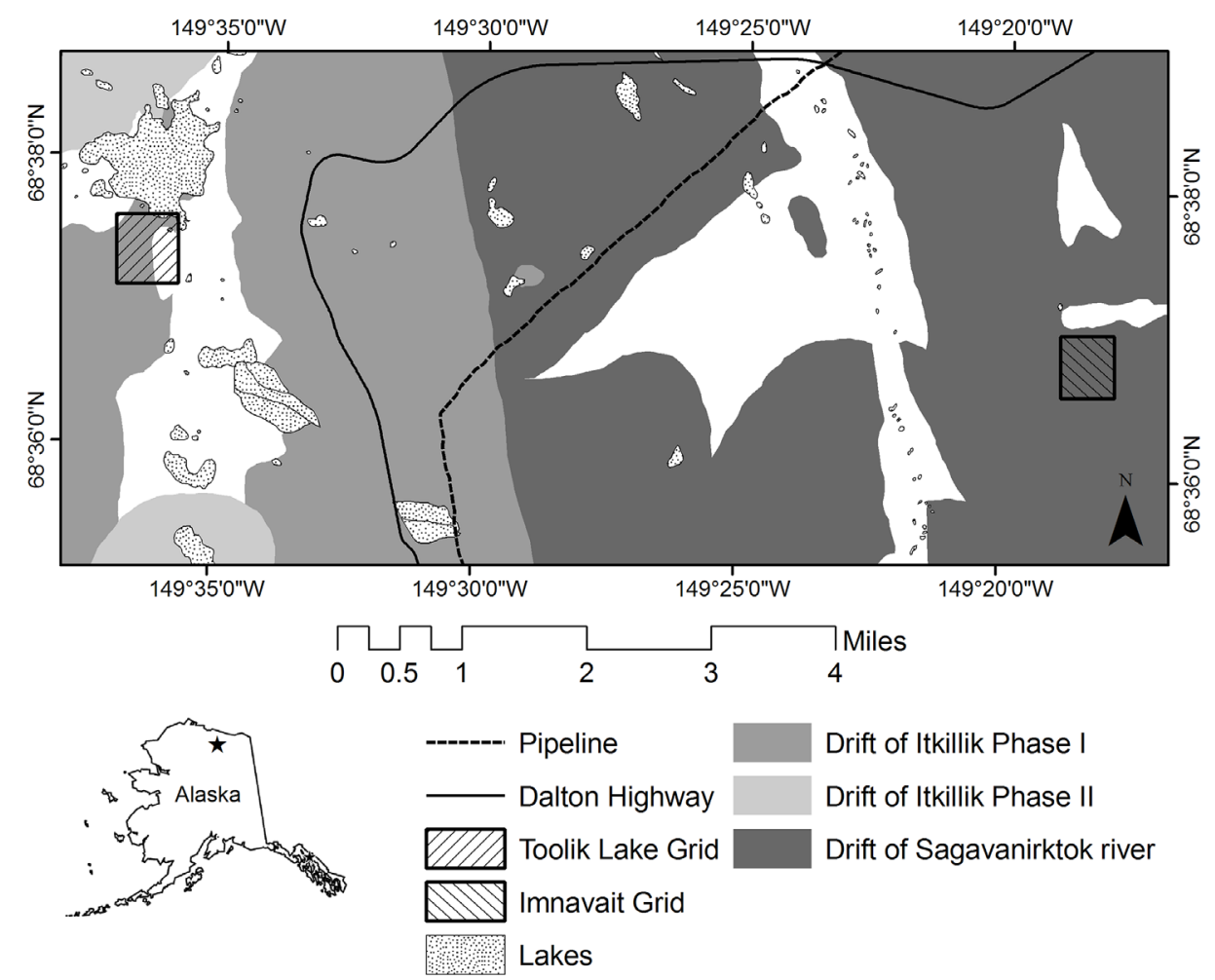

Figure 1. Landscape ages and the location of the Toolik Lake and Imnavait Creek $1 \mathrm{~km}^{2}$ grids in the Upper Kuparuk River region in Northern Alaska. 
dominated by gently rolling hills and elevation within the watershed varies from about 770 to $980 \mathrm{~m}$ [22]. Most of the Toolik Lake grid lies in a younger substrate (Itkillik I glacial drift) which deglaciated during the late Pleistocene (ca. 55,000 years), but includes areas of Itkillik II outwash towards the east [27] [28]. The landscape at this site is more heterogeneous than at Imnavait and is dominated by small glacial lakes, kames and moraines. Elevations range from 670 to $850 \mathrm{~m}$ [18].

Both grids share similar meteorological conditions due to their close proximity $(<12 \mathrm{~km})$. Mean annual surface atmospheric temperature (SAT) from $1989-2008$ have been $-8.5^{\circ} \mathrm{C}$; whereas average annual precipitation during the same period was $312 \mathrm{~mm}$ [29]. Linear trend analysis of mean annual SAT and mean annual precipitation revealed no trends in these parameters suggesting that they have remained stable over the last two decades [29].

\subsection{Study Design}

There are 157 permanent $1 \mathrm{~m}^{2}$ vegetation plots within these grids, 72 at Imnavait and 85 at Toolik. Plots are located equidistantly at 100 meters from each other within the grids [19]. These are non-manipulative plots that are currently being studied for analyzing long term changes in vegetation composition and structure in this region [30]. We limited our analysis to a subset of these plots that are established in areas with Sphagno-Eriophoretum vaginati plant communities. This plant community has a broad spatial extent which allows us to extrapolate results to a landscape-scale level. Likewise, confounding effects that may result from grid-scale variation in plant communities could be reduced by focusing on a single plant community. The Sphagno-Eriophoretum vaginati plant community is the most dominant plant community within the grids and is considered the zonal vegetation of mesic slopes throughout the Arctic Foothills [18]. It typically occurs on ice-rich sediments with shallow active layers and low soil $\mathrm{pH}$ [31]. The most conspicuous plant species is the tussock-forming sedge Eriophorum vaginatum which dominates particularly in stable hillslope shoulders and upper backslopes; whereas shrubs like Betula nana and Salix pulchra tend to become dominant on footslopes and associate with deep Sphagnum spp. mats, other mosses like Aulacomnium turgidum, Hylocomnium splendens and lichens like Peltigera aphtosa and Cladonia spp. [18] [22] [32]. Sphagno-Eriophoretum vaginati plant communities' sensu Walker et al. [18] are contained within the Moist-tussock sedge, dwarf shrub, moss tundra physiognomic unit [24] and mostly coincide with Eriophorum vaginatum-Sphagnum spp. plant communities' sensu Walker et al. [22].

Plant communities within the Toolik and Imnavait grids were identified using geographical layers prepared by Walker [33] and published maps of the region [24]. There are 33 vegetation types represented in the Upper Kuparuk river region [22] [31]. Walker et al. [18] classified vegetation of both Toolik and Imnavait grids into five associations and 15 community types. We performed an overlay analysis using a geographic information system (GIS) and selected 24 plots (12 at Toolik and 12 at Imnavait) representing Sphagno-Eriophoretum vaginati plant communities. We extracted growth form abundance data from selected plots from a long-term plant community dataset. This data corresponded to vegetation sampling realized in 2007 (Imnavait) and 2008 (Toolik) [34].

\subsection{Sampling and Nutrient Analysis}

Soil samples were collected 1 - 2 meters apart from selected plots in areas with visually similar vegetation composition. Samples of organic and mineral soils were collected near each plot following the procedures described below. Mineral soils near two of the 24 plots (both at Toolik) were frozen at the time of collection and not sampled. Soil sampling was realized during August, 2008.

A shovel was used to create a $25 \times 25 \mathrm{~cm}$ pit to collect soil samples in each selected plot. Pits reached an approximate depth of $20 \mathrm{~cm}$, or deeper until the upper $5-7 \mathrm{~cm}$ portion of the mineral horizon was exposed. Three samples of mineral soils $(n=3)$ were taken at each pit by pushing a stainless steel soil core with plastic core inserts (aprox. $98 \mathrm{cc}$.) horizontally into the soil profile. These samples were used individually to calculate soil moisture, bulk density and elemental concentrations in this horizon. Mineral soil moisture was calculated after oven drying samples at $105^{\circ} \mathrm{C}$ for 48 hours in laboratory facilities at Toolik Lake Field Station. Depending on soil conditions, each organic soil sample $(n=1)$ was extracted horizontally at the soil profile or vertically using a small bread knife and were then placed into labeled cloth bags. When samples were collected vertically, we removed the upper layer of soil where live material was evident and the lower layer where the organic layer diffuses into the mineral soil layer. Each organic soil sample had approximately twice the volume of mineral soil 
samples. All samples (except those used for estimating mineral soil moisture) were sent to the International Institute of Tropical Forestry Soils Laboratory (USDA-USFS) in San Juan, Puerto Rico and were processed within 8 days. Mineral soil samples for elemental concentration and bulk density determinations were oven dried at $40^{\circ} \mathrm{C}$ for two weeks, whereas those from organic soils were air dried over the same period. We used a Foss Tecator Cyclotec (model 1093) mill to ground the samples and then passed them through a $1 \mathrm{~mm}$ stainless steel sieve. Roots of considerable size and other live material were excluded from the samples.

Total Nitrogen $(\mathrm{N})$ and Total Carbon (C) were analyzed using the dry combustion method by means of a LECO TruSpec CN Analyzer [35]. The procedure used is a modified version of the Organic Application Note titled "Carbon and Nitrogen in Soil and Sediment" obtained from LECO Corp. [36]. The dry combustion method was also used to determine Total Sulfur (S), utilizing the LECO TruSpec (Add-On Module) S Analyzer [37]. The procedure used is from LECO [38] and is titled "Sulfur in Cement, Fly Ash, Limestone, Soil, and Ore". In the dry combustion method a small weighted sample is combusted in a high temperature furnace $\left(950^{\circ} \mathrm{C}\right.$ for the LECO TruSpec CN Analyzer and $1450^{\circ} \mathrm{C}$ for the LECO TruSpec S Analyzer) and in a stream of purified oxygen. Total Carbon is measured as $\mathrm{CO}_{2}$ by an infrared detector and Total Nitrogen is determined as $\mathrm{N}_{2}$ by a thermal conductivity cell detector. Total Sulfur as $\mathrm{SO}_{2}$ is also detected by an infrared.

Ground material was analyzed for elemental concentrations of Phosphorus (P), Aluminum (Al), Potassium (K), Calcium (Ca), Magnesium (Mg), Manganese (Mn), Sodium (Na) and Iron (Fe). Soil samples were digested with concentrated $\mathrm{HNO}_{3}, 30 \% \mathrm{H}_{2} \mathrm{O}_{2}$ and concentrated $\mathrm{HCl}$ using a modified version of the method recommended by Luh Huang and Schulte [39] and analyzed by means of a Spectro Plasma Emissions Spectrometer (Spectro Ciros ICP).

Subsamples were oven dried at $105^{\circ} \mathrm{C}$ for $24 \mathrm{hrs}$. A moisture factor was calculated and applied to each analysis [40]. These same subsamples were later ignited at $490^{\circ} \mathrm{C}$ in a muffle furnace (for at least $8 \mathrm{hrs}$.) to determine Loss-on-Ignition (LOI). Soil pH was measured in a 1:1 (soil:water) solution using an Orion Ionanalyzer Model 901 with a combination $\mathrm{pH}$ electrode [41].

Soil moisture of mineral and organic soil samples was determined by calculating the percentage weight loss after drying. Organic horizon thickness was averaged for each plot and was calculated using three different measurements of the organic horizon width at randomly selected areas of each pit.

\subsection{Statistical Analysis}

We analyzed and treated as independent variables each physico-chemical parameter and the abundance of particular growth forms. We used Exploratory Data Analysis (EDA) to corroborate if these variables conformed to parametric testing assumptions. We assessed normality using the Shapiro-Wilk test along with Normal Q-Q plots. Except for "\% Moisture" which was analyzed using non-parametric Mann-Whitney $U$-test, results from EDA supported the use of Independent Samples T-Test for most variables. Variables that initially failed EDA tests were mostly affected by few extreme outliers and behave normally after their exclusion.

We used Pearson's correlation coefficient ( $r$ ) to evaluate how physico-chemical parameters that were significantly different between sites relate to growth forms that were also found to have significantly different abundances at each site. We combined data from both sites that corresponded to these two variables. This resulted in 22 data points for correlation analysis. Correlation tests were performed after absolute abundances values in the dataset were converted to percent cover of growth forms at each plot.

\section{Results}

We found no significant differences between Imnavait and Toolik in terms of the thickness of the organic horizon and the bulk density of the mineral horizon (Table 1). Soils at both sites were similarly acidic whereas comparable LOI values are indicative of similar organic matter content. Only percent moisture was significantly higher in mineral soils from Imnavait vs. Toolik. Nonetheless, higher moisture recorded at Imnavait is possibly linked to higher precipitation activity that was observed at this site during sampling.

There were no differences in the concentration of $\mathrm{C}, \mathrm{N}$ and $\mathrm{S}$ between both sites for both organic and mineral horizons (Figure 2(a), Figure 2(b) and Table 1). There were also no significant differences between sites for the concentration of other elements, except for $\mathrm{Ca}$ which was significantly higher in organic horizons of the older Imnavait site $(\mathrm{M}=5.56, \mathrm{SD}=4.21)$ compared to the younger Toolik site $(\mathrm{M}=2.74, \mathrm{SD}=1.97), t(21)=2.09$, $\mathrm{p}<0.05$ (Figure $3(\mathrm{a})$ ) and $\mathrm{Na}$ which was significantly higher in mineral soils of Toolik $(\mathrm{M}=0.27, \mathrm{SD}=0.07)$ 
Table 1. Physical and chemical properties of mineral and organic soils from the Sphagno-Eriophoretum vaginati plant communities in Toolik Lake and Imnavait Creek grids. Between-site comparisons were assessed with Independent Samples T-Test unless otherwise noted. Sample size within parentheses unless otherwise indicated with superscripts. SD $=$ Standard deviation. Statistical significance achieved at $\mathrm{p}<0.05$.

\begin{tabular}{|c|c|c|c|c|c|c|c|c|c|c|}
\hline \multirow{3}{*}{ Variables } & \multicolumn{4}{|c|}{ Mineral } & \multirow{3}{*}{ p-values } & \multicolumn{4}{|c|}{ Organic } & \multirow{3}{*}{ p-values } \\
\hline & \multicolumn{2}{|c|}{ Imnavait $(\mathrm{n}=12)$} & \multicolumn{2}{|c|}{ Toolik $(\mathrm{n}=10)$} & & \multicolumn{2}{|c|}{ Imnavait $(\mathrm{n}=12)$} & \multicolumn{2}{|c|}{ Toolik $(\mathrm{n}=12)$} & \\
\hline & Mean & SD & Mean & SD & & Mean & SD & Mean & SD & \\
\hline \multicolumn{11}{|l|}{ Total elements } \\
\hline C (\%) & $3.41^{\mathrm{a}}$ & 2.13 & $4.01^{\mathrm{c}}$ & 1.84 & $\mathrm{~ns}$ & 34.85 & 7.36 & 29.15 & 10.74 & $\mathrm{~ns}$ \\
\hline $\mathrm{N}(\%)$ & $0.14^{\mathrm{a}}$ & 0.12 & $0.15^{\mathrm{c}}$ & 0.10 & ns & 1.55 & 0.34 & 1.24 & 0.47 & ns \\
\hline $\mathrm{S}(\%)$ & $0.02^{\mathrm{a}}$ & 0.01 & $0.02^{\mathrm{c}}$ & 0.01 & ns & 0.19 & 0.05 & 0.17 & 0.08 & ns \\
\hline $\mathrm{Al}(\mathrm{mg} / \mathrm{g})$ & $12.18^{\mathrm{a}}$ & 3.55 & 11.88 & 2.75 & ns & 8.57 & 4.78 & 8.70 & 3.09 & ns \\
\hline $\mathrm{P}(\mathrm{mg} / \mathrm{g})$ & 0.45 & 0.19 & $0.45^{\mathrm{c}}$ & 0.18 & $\mathrm{~ns}$ & 1.51 & 0.44 & 1.37 & 0.67 & ns \\
\hline $\mathrm{Na}(\mathrm{mg} / \mathrm{g})$ & $0.17^{\mathrm{b}}$ & 0.10 & 0.27 & 0.07 & $\mathrm{p}<0.05$ & 1.49 & 0.87 & 1.26 & 0.55 & $\mathrm{~ns}$ \\
\hline $\mathrm{Mn}(\mathrm{mg} / \mathrm{g})$ & $0.30^{\mathrm{a}}$ & 0.20 & 0.26 & 0.20 & ns & 6.70 & 7.80 & $4.81^{\mathrm{a}}$ & 7.48 & $\mathrm{~ns}$ \\
\hline $\mathrm{Ca}(\mathrm{mg} / \mathrm{g})$ & $0.79^{\mathrm{a}}$ & 0.30 & 0.86 & 0.37 & $\mathrm{~ns}$ & $5.56^{\mathrm{a}}$ & 4.21 & 2.74 & 1.97 & $\mathrm{p}<0.05$ \\
\hline $\mathrm{Fe}(\mathrm{mg} / \mathrm{g})$ & 27.20 & 7.82 & 27.51 & 8.26 & $\mathrm{~ns}$ & $25.36^{\mathrm{a}}$ & 12.64 & 22.32 & 12.27 & $\mathrm{~ns}$ \\
\hline $\mathrm{Mg}(\mathrm{mg} / \mathrm{g})$ & $2.48^{\mathrm{a}}$ & 0.84 & 2.14 & 0.28 & $\mathrm{~ns}$ & $1.38^{\mathrm{a}}$ & 0.33 & 1.14 & 0.53 & $\mathrm{~ns}$ \\
\hline $\mathrm{K}(\mathrm{mg} / \mathrm{g})$ & $0.73^{\mathrm{a}}$ & 0.27 & 0.79 & 0.20 & $\mathrm{~ns}$ & $0.84^{\mathrm{a}}$ & 0.22 & 0.78 & 0.26 & $\mathrm{~ns}$ \\
\hline $\begin{array}{l}\text { Organic horizon thickness } \\
\qquad(\mathrm{cm} ; \mathrm{n}=3)\end{array}$ & - & - & - & - & - & 13.04 & 1.22 & $10.63^{\mathrm{c}}$ & 1.88 & ns \\
\hline Bulk density (g/cc) & 1.25 & 0.14 & 1.46 & 0.12 & ns & - & - & - & - & - \\
\hline$\%$ Moisture & 30.34 & 19.02 & 12.65 & 15.84 & $\mathrm{p}<0.05^{*}$ & - & - & - & - & - \\
\hline LOI (\%) & 10.52 & 6.18 & $9.88^{\mathrm{c}}$ & 3.48 & $\mathrm{~ns}$ & 68.64 & 12.95 & 58.23 & 19.74 & $\mathrm{~ns}$ \\
\hline $\mathrm{pH}\left(\mathrm{H}_{2} \mathrm{O}\right)$ & 4.53 & 0.12 & 4.41 & 0.19 & ns & 4.80 & 0.72 & 4.34 & 0.53 & ns \\
\hline
\end{tabular}

${ }_{\mathrm{a}}^{\mathrm{a}}=11 ;{ }^{\mathrm{b}} \mathrm{n}=10 ;{ }^{\mathrm{c}} \mathrm{n}=9 ;{ }^{*}$ Mann-Whitney $U$-test.

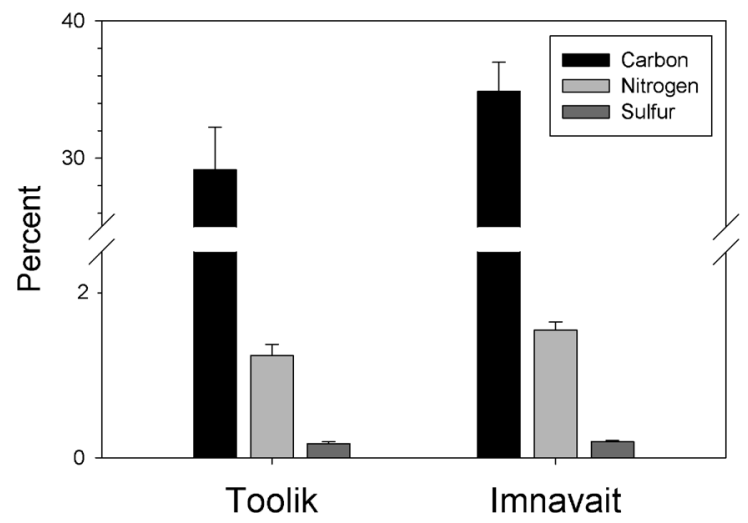

(a)

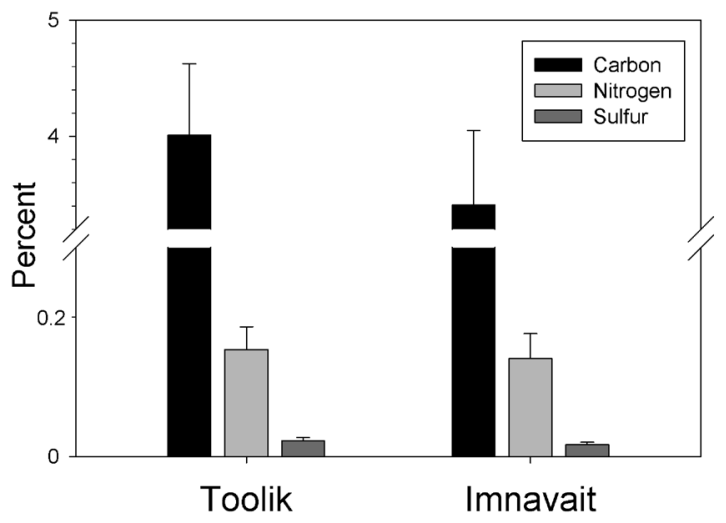

(b)

Figure 2. Differences between Toolik Lake and Imnavait Creek grids in terms of mean total concentration (\%) of C, N and $\mathrm{S}$ in (a) organic horizons and (b) mineral horizons.

compared to Imnavait $(\mathrm{M}=0.17, \mathrm{SD}=0.10), t(20)=2.75, \mathrm{p}<0.05$ (Figure 3(b) and Table 1).

We found significant between-site differences in the abundances of several growth forms (Table 2 and Figure 4). The abundance of shrubs was significantly higher at Toolik $(\mathrm{M}=32.25, \mathrm{SD}=5.36)$ vs. Imnavait ( $\mathrm{M}$ $=26.51, \mathrm{SD}=7.04) ; t(22)=-2.25, \mathrm{p}<0.05$. In contrast, forbs were significantly more abundant at Imnavait $(\mathrm{M}$ $=5.99, \mathrm{SD}=5.52)$ vs. Toolik $(\mathrm{M}=1.60, \mathrm{SD}=1.69) ; t(22)=2.64, \mathrm{p}<0.05$. Similarly, non-Sphagnum mosses at Imnavait $(\mathrm{M}=27.42, \mathrm{SD}=4.92)$ were more abundant than at Toolik $(\mathrm{M}=10.60, \mathrm{SD}=5.31) ; t(22)=8.05, \mathrm{p}<0.00$, 


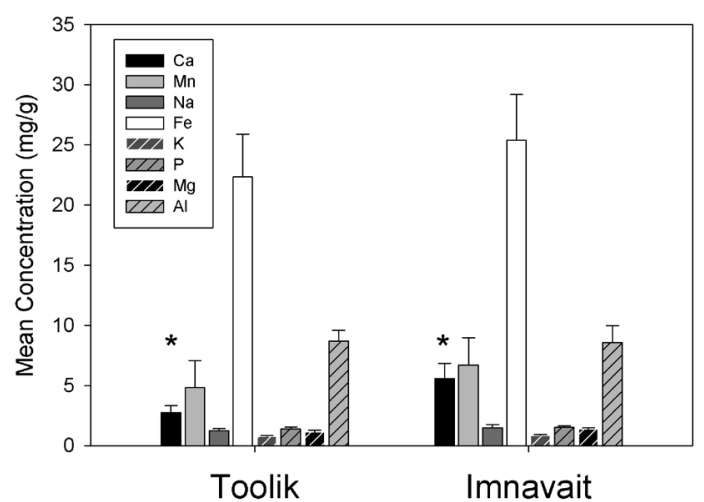

(a)

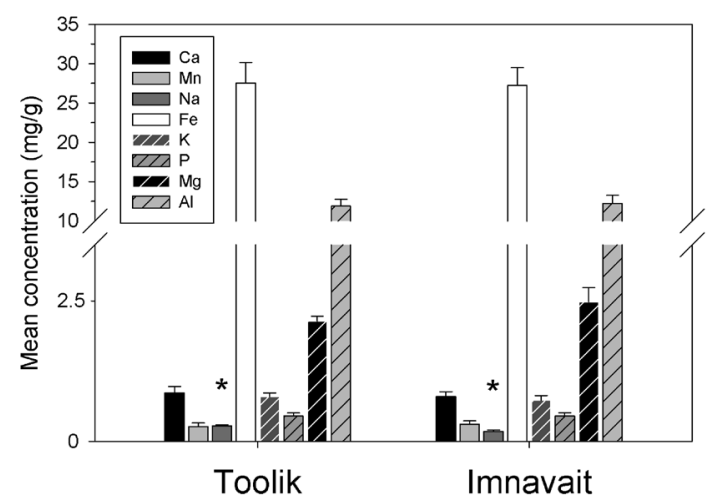

(b)

Figure 3. Differences between Toolik Lake and Imnavait Creek grids in terms of mean total concentration (mg/g) of Ca, $\mathrm{Mn}, \mathrm{Na}, \mathrm{Fe}, \mathrm{K}, \mathrm{P}, \mathrm{Mg}$ and $\mathrm{Al}$ in (a) organic horizons and (b) mineral horizons. Asterisks indicate significant differences ( $\mathrm{p}$ $<0.05)$.

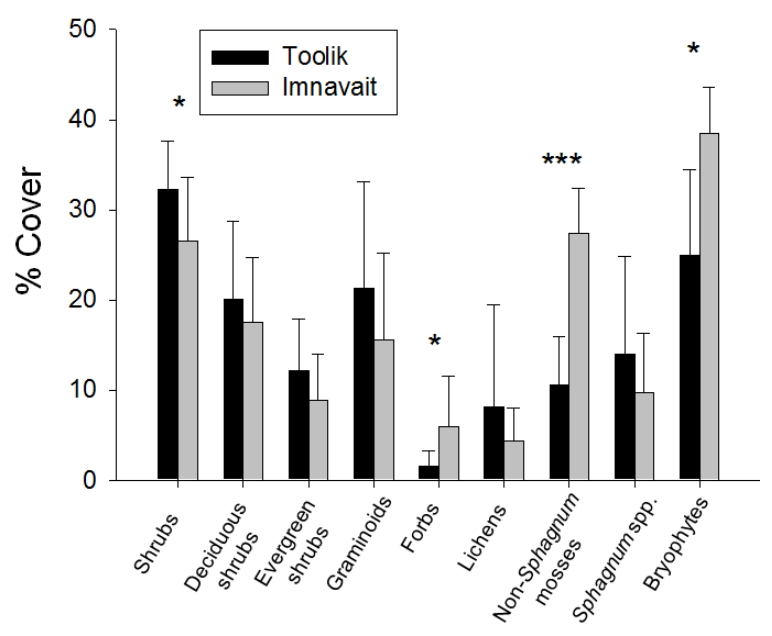

Growth forms

Figure 4. Differences between Toolik Lake and Imnavait Creek grids in terms of mean abundance of growth forms (\% Cover). Abundance data correspond to years 2007-2008. Asterisks indicate significant differences $(\mathrm{p}<0.05)$.

Table 2. Abundances (\% Cover) of main growth forms in 24 one meter squared plots with vegetation classified as Sphagno-Eriophore- tum vaginati plant community. Abundance data correspond to years 2007-2008. Between-site comparisons were assessed with Independent Samples T-Test. Sample size within parentheses unless otherwise indicated with superscripts. $\mathrm{SD}=$ Standard deviation. Statistical significance achieved at $\mathrm{p}<0.05$.

\begin{tabular}{|c|c|c|c|c|c|c|}
\hline \multirow{2}{*}{ Type } & \multirow{2}{*}{ Growth form } & \multirow{2}{*}{$\begin{array}{c}\text { Toolik } \\
\text { Mean }(n=12)\end{array}$} & \multicolumn{3}{|c|}{ Imnavait } & \multirow{2}{*}{$\mathrm{p}$-values } \\
\hline & & & $\mathrm{SD}$ & Mean $(n=12)$ & $\mathrm{SD}$ & \\
\hline \multirow{5}{*}{ Vascular } & Shrubs & 32.25 & 5.36 & 26.51 & 7.04 & $<0.05$ \\
\hline & Deciduous shrubs & 20.12 & 8.61 & 17.56 & 7.21 & ns \\
\hline & Evergreen shrubs & 12.13 & 5.77 & 8.94 & 5.06 & ns \\
\hline & Graminoids & 21.31 & 11.77 & 15.63 & 9.52 & ns \\
\hline & Forbs & 1.60 & 1.69 & 5.99 & 5.52 & $<0.05$ \\
\hline \multirow{4}{*}{ Non-vascular } & Lichens & 8.14 & 11.39 & 4.44 & 3.59 & ns \\
\hline & Non-Sphagnum mosses & 10.60 & 5.31 & 27.42 & 4.92 & $<0.001$ \\
\hline & Sphagnum spp. & 13.96 & 10.93 & 9.68 & 6.65 & ns \\
\hline & Bryophytes & 24.99 & 9.45 & 38.50 & 5.07 & $<0.05$ \\
\hline
\end{tabular}


and bryophytes more abundant at Imnavait $(\mathrm{M}=38.50, \mathrm{SD}=5.07)$ than at Toolik $(\mathrm{M}=24.99, \mathrm{SD}=9.45) ; t(22)$ $=4.36, \mathrm{p}<0.05$.

Because $\mathrm{Ca}$ in organic soils and $\mathrm{Na}$ in mineral soils were the only elements exhibiting a statistically significant difference between sites, correlation analysis was focused on evaluating the relationship of these two elements with the abundance those growth forms found to have contrasting abundances between sites. In this sense, we found the abundance of non-Sphagnum mosses to be positively correlated with the total concentration of $\mathrm{Ca}$ in organic soils $(r=0.48, n=24, p<0.05)$. We also found that the total concentration of $\mathrm{Na}$ in mineral soils was negatively correlated with the abundances of forbs $(\mathrm{r}=-0.486, \mathrm{n}=22, \mathrm{p}<0.05)$, non-Sphagnum mosses $(\mathrm{r}=$ $-0.470, \mathrm{n}=22, \mathrm{p}<0.05)$ and bryophytes $(\mathrm{r}=-578, \mathrm{n}=22, \mathrm{p}<0.01)$.

\section{Discussion}

Determinations of several physico-chemical parameters, including total C, N and S and other elemental concentrations of soils occurring in Sphagno-Eriophoretum vaginati plant communities at Toolik Lake and Imnavait Creek grids, indicate that for most elements evaluated, and in spite of a $70 \mathrm{k}$ year difference in landscape age, there are no significant differences between sites. In general, main patterns observed for many of the variables measured are not distant to what has been reported previously for this area [3] [5]-[7] [9] [23] [42]-[45]. Our observations confirm that both sites have similar soil acidity [3] [5] [43] and mineral soils bulk density values comparable to those reported in other studies [7] [42]. As expected, and in accordance with most of these studies, total $\mathrm{C}$ for both Toolik and Imnavait was 7 to 10 times larger in organic soils vs. mineral soils. Total $\mathrm{N}$ exhibited a similar pattern. There were no significant differences between Toolik and Imnavait in terms of the total concentration of both $\mathrm{C}$ and $\mathrm{N}$ in organic and mineral soils, hence confirming observations made by Whittinghill and Hobbie [5]. No between-site differences were found in terms of the amount of S in both organic and mineral soils, still, the concentration of this element in these soils is almost negligible.

Although some of our findings serve mostly as a confirmation of previously reported similarities in elemental concentrations between these two areas [5] [6] [24], others represent intriguing aspects of the soil chemistry of this region that are worth highlighting. For instance, similar to findings of Keller et al. [23], Fe had the largest concentration in both mineral and organic soils at both sites. Studies have demonstrated that Fe (as well as Al, the second highest) tends to accumulate in soils from tundra and other ecosystems [46]-[49]. Moreover, $\mathrm{Fe}$ is more soluble in acidic soils; therefore its availability tends to increase under these conditions [46] [50]. High concentrations of $\mathrm{Al}$ and $\mathrm{Fe}$ have been linked to substantial increases in the sorption capacity of organic soils. This situation may lead to reductions in P availability, causing plants to become P limited [47] [51] [52]. These observations suggest that due to its effect on $\mathrm{P}$ availability, changes in the concentration of $\mathrm{Fe}$ or $\mathrm{Al}$ in these soils could affect significantly the vegetation in this region. This is particularly relevant for wet sedge and some MAT areas where $\mathrm{P}$ availability is known to limit primary productivity [53] [54].

We consider atypical the higher concentration of $\mathrm{Ca}$ in organic soils from Imnavait. Organic soils from both sites have similar $\mathrm{pH}$. Because soil $\mathrm{pH}$ is known to affect the availability of $\mathrm{Ca}$ [12] [46], contrasting Ca concentrations are expected to be more commonly be found between soils with significantly different acidity, as is the case for MAT vs. MNT tundra [3] [7], and less frequently between areas with the same type of vegetation (MAT), such as Toolik and Imnavait. Accordingly, Whittinghill and Hobbie [5] found that exchangeable Ca concentrations were not significantly different between soils derived from the landscape ages represented by these sites. It is likely that higher total $\mathrm{Ca}$ in organic soils from Imnavait is linked to differences in landscape age between these sites. This observation would agree with findings from Keller et al. [23] which found that organic and mineral horizons from Sagavanirktok glacial surfaces had higher $\mathrm{Ca}$ concentration than soils from Itkillik I surfaces (not statistically corroborated). Perhaps other processes that were not evaluated in this study, such as those related to biological and/or chemical immobilization, are variable in soils from these two landscape ages, and may account for some of these differences. However, as evidenced in this study, it is likely that the total Ca in organic soils is being influenced by between-site differences in vegetation composition, specifically, the abundance of non-Sphagnum mosses. In general, bryophytes tend to be in direct contact with underlying organic soils in these ecosystems and usually exert an influence on a number of soil processes [55]. Compared to Toolik, Imnavait had a significantly higher abundance of non-Sphagnum mosses and significantly higher concentration of $\mathrm{Ca}$ in organic soils, which agrees with the positive correlation found between these two parameters. Considering that both sites are influenced by similar climate and that plots are located in terrain of similar relief, 
dominated by MAT tundra; it seems plausible that besides landscape age, subtle variation in the abundance of non-Sphagnum mosses is contributing towards the differentiation of Sphagno-Eriophoretum vaginati plant community areas in terms of total $\mathrm{Ca}$ in organic soils. The work of van der Welle [56] partly support this hypothesis and revealed a significant positive correlation between non-Sphagnum moss cover and soil Ca content in several tussock tundra sites. Nevertheless, it remains to be tested if the effect of contrasting abundances on organic soil Ca concentration occurs via specific plant traits, like between-species variation in tissue concentration of this element, or via other plant community factors, like differences in species richness of non-Sphagnum mosses.

In terms of its ecosystemic effects, a higher total $\mathrm{Ca}$ in Imnavait soils imply that there may be less available substrate for microbial activity at that site. This is expected to diminish microbial respiration due to stabilization of organic matter by cation bridging with Ca ions [6]. However, rates of microbial activity are higher on older, more acidic landscapes [5] [8] [9] which may partly compensate for the effects of higher Ca on microbial respiration in these soils.

A significantly higher concentration of $\mathrm{Na}$ in minerals soils of Toolik was an unexpected finding considering that total $\mathrm{Na}$ have been found to be higher in mineral soils from Sagavarnirktok vs. Itkillik I glacial surfaces [23] (not statistically corroborated). However, because the dynamics of $\mathrm{Na}$ in mineral soils has not been characterized thoroughly in this region, we believe that between-site differences in the chemical composition of the parent material, perhaps the presence of Na-rich bedrock in sampled plots at Toolik, would be the most logical explanation for these observations. Although less likely, part of this dissimilarity might also be tied to differences in vegetation composition. Contrary to patterns observed between the abundance of non-Sphagnum mosses and total $\mathrm{Ca}$ in organic soils, significantly lower abundances of forbs, non-Sphagnum mosses and bryophytes in Toolik are responsible for the observed negative correlation between these growth forms and total Na in mineral soils. Assuming that forbs and bryophytes have low $\mathrm{Na}$ tissue concentration compared to other growth forms, it could be argued that in areas where they flourish (like Toolik), soils could reflect low Na concentration. However, in first instance, this assumption is undermined by the general scarcity of information regarding the concentration of $\mathrm{Na}$ in tissues of tundra plant species. Additionally, the effect of these growth forms on deeper mineral soil biogeochemical processes is expected to be negligible considering that their vertical distribution is limited to upper soil layers. Lastly, higher $\mathrm{Na}$ in mineral soils at Toolik might also be linked to other factors not evaluated in this study, for example, between-site variation in rates of chemical weathering of parent materials.

Soil $\mathrm{Na}$ has not been properly characterized in studies of soil chemistry in tundra ecosystems, except for few notable studies [3] [7] [23]. As an element, $\mathrm{Na}$ is present in small quantities in soils and is not an essential element for plant growth. Nevertheless, Na concentration in soils or water has been shown to promote maximal biomass yield and perform other important functional roles in plants [57]. High levels of Na could be detrimental to soil structure, soil permeability and plant growth, and in spite of its overall low levels, projected climate warming in tundra ecosystems may result in reduced soil moisture conditions [58] which may in turn affect $\mathrm{Na}$ dynamics in soils. Under this scenario, it becomes important to increase efforts towards a better understanding of $\mathrm{Na}$ dynamics in tundra soils as they are likely to change under a warming climate.

Based on our results and those of others [5] [6] [23] [42]-[44], it is evident that landscape age differences between our sites do not result in a robust chemical imprint that might help discriminate these sites in terms of their soil physico-chemical properties. While we were able to detect significant differences in two (Ca in organic soils and $\mathrm{Na}$ in mineral soils) of the 11 chemical parameters evaluated, these differences are subtle compared to the conspicuous differences in concentration of other elements, like Ca, between MAT and MNT [5] [7]. It has been recognized that variation in elemental concentrations in tundra soils of the Toolik-Imnavait region are tied to larger landscape-scale factors like changes in vegetation physiognomy and $\mathrm{pH}$ which show considerable variation at different spatial and temporal scales in this region [1] [3] [5] [7] [9] [18] [23]. Additionally, other processes like cryoturbation and frost boil formation could cause the continuous movement and mixing of soil material [3] [15] [59], thus preventing long term soil stability and causing continuous homogenization of nutrients throughout soil horizons [42] [60]. Freeze-thaw processes like cryoturbation are more frequent on MNT [3] [61], though discontinuous surface organic horizons resulting from cryoturbation are common throughout the southern foothills [62]. Therefore, we suggest that while possibly occurring in a lower frequency and magnitude, these processes are at least partly responsible for the little differentiation that organic and mineral soils of these two sites reflect in terms of most of the elemental concentrations and other physico-chemical properties evaluated in this study. 
Most importantly, after detecting the differences between Toolik and Imnavait in terms of the concentration of $\mathrm{Ca}$ in organic soils and $\mathrm{Na}$ in mineral soils, we were able to discern that abundance patterns of several growth forms at these sites were concordant with correlations found between these growth forms and the concentration of these elements in organic and mineral soils respectively. These observations are relevant as they demonstrate that minimal differences in soil chemistry, possibly linked to contrasting landscape ages between these two sites, are influencing aboveground patterns in vegetation composition. In turn, by directly influencing the biophysical environment through variation in moisture or temperature regimes, through differences in root mycorrhizal processes [33], or by indirectly influencing the rates of litter input and decomposability [8], this variation in vegetation composition could be reciprocally influencing soil chemistry, therefore perpetuating the differentiation between these two sites in terms of these two elements.

\section{Conclusion}

Investigations analyzing the relationship between soil chemistry and vegetation in tundra ecosystems in this region have shown that conspicuous soil chemical differences (e.g. $\mathrm{pH}$ and $\mathrm{Ca}$ concentration) between some different aged landscapes (e.g. Itkillik II vs. Itkillik I) are accompanied by notable differences in vegetation types (MAT vs. MNT) [3] [7] [9]. In this respect, our study indicates that soil evolution may be governed by vegetation cover as much as by time. Landscapes of different age (Itkillik I vs. Sagavariktok) and very similar vegetation type (i.e., MAT) are not distinguishable in terms of most of their soil physical and chemical properties. However, total concentration of elements like $\mathrm{Ca}$ and $\mathrm{Na}$ may vary between them. This variation, although likely linked to differences in the chemical composition of the geologic substrates underlying these soils, appears to reflect some level of agreement with abundance patterns of specific growth forms. These observations are relevant as they testify in favor of the reciprocal relationship between soil chemistry and vegetation composition in moist acidic tundra landscapes in Arctic Alaska.

\section{Acknowledgements}

We thank Amy Breen Carroll and Sayuri Ito for their work during the collection of soil samples. We are profoundly grateful to the personnel of the IITF Chemistry Laboratory for helping in the analysis and interpretation of soil chemical results. Thanks to the staff of the Toolik Lake Field Station (UAF) for their hospitality and for coordination of laboratory space. Ariel E. Lugo reviewed the original version of the manuscript and provided helpful comments. This work is based on support by the United States National Science Foundation awards OPP-0632277 and OPP-0856710. This research was conducted in cooperation with the University of Puerto Rico.

\section{References}

[1] Marion, G.M., Hastings, S.J., Oberbauer, S.F. and Oechel, W.C. (1989) Soil-Plant Element Relationships in a Tundra Ecosystem. Holarctic Ecology, 12, 296-303.

[2] Walker, D.A., Auerbach, N.A. and Shippert, M.M. (1995) NDVI, Biomass, and Landscape Evolution of Glaciated Terrain in Northern Alaska. Polar Record, 31, 169-178. http://dx.doi.org/10.1017/S003224740001367X

[3] Bockheim, J.G., Walker, D.A., Everett, L.R., Nelson, F.E. and Shiklomanov, N.I. (1998) Soils and Cryoturbation in Moist Non-Acidic and Acidic Tundra in the Kuparuk River Basin, Arctic Alaska, USA. Arctic and Alpine Research, 30, 166-174. http://dx.doi.org/10.2307/1552131

[4] Walker, D.A. (2000) Hierarchical Subdivision of Arctic Tundra based on Vegetation Response to Climate, Parent Material and Topography. Global Change Biology, 6, 19-34. http://dx.doi.org/10.1046/j.1365-2486.2000.06010.x

[5] Whittinghill, K.A. and Hobbie, S.E. (2011) Effects of Landscape Age on Soil Organic Matter processing in Northern Alaska. Soil Science Society of America Journal, 75, 907-917. http://dx.doi.org/10.2136/sssaj2010.0318

[6] Whittinghill, K.A. and Hobbie, S.E. (2011) Effects of pH and Calcium on Soil Organic Matter Dynamics in Alaskan Tundra. Biogeochemistry, 111, 569-581. http://dx.doi.org/10.1007/s10533-011-9688-6

[7] Hobbie, S.E. and Gough, L. (2002) Foliar and Soil Nutrients in Tundra on Glacial Landscapes of contrasting Ages in Northern Alaska. Oecologia, 131, 453-462. http://dx.doi.org/10.1007/s00442-002-0892-x

[8] Hobbie, S.E. and Gough, L. (2004) Litter Decomposition in Moist Acidic and Non-Acidic Tundra with different Glacial Histories. Oecologia, 140, 113-124. http://dx.doi.org/10.1007/s00442-004-1556-9

[9] Hobbie, S.E., Miley, T.A. and Weiss, M.S. (2002) Carbon and Nitrogen Cycling in Soils from Acidic and Non Acidic 
Tundra with Different Glacial Histories in Northern Alaska. Ecosystems, 5, 761-774. http://dx.doi.org/10.1007/s10021-002-0185-6

[10] Walker, D.A. and Walker, M.D. (1996) Terrain and Vegetation of the Imnavait Creek Watershed. In: Reynolds, J.F. and Tenhunen, J.D., Eds., Landscape Function and Disturbance in Arctic Tundra Ecological Studies, Vol. 120, Springer-Verlag, Berlin, 73-108. http://dx.doi.org/10.1007/978-3-662-01145-4 4

[11] Walker, D.A., Epstein, H.E., Jia, G.J., Balser, A., Copass, C., Edwards, E.J., Gould, W.A., Hollingsworth, J., Knudson, J., Maier, H.A., Moody, A. and Raynolds, M.K. (2003) Phytomass, LAI, and NDVI in Northern Alaska: Relationships to Summer Warmth, Soil pH, Plant Functional Types, and Extrapolation to the Circumpolar Arctic. Journal of Geophysical Research, 108, 8169-8185. http://dx.doi.org/10.1029/2001JD000986

[12] Gough, L., Shaver, G.R., Carroll, J., Royer, D.L. and Laundre, J.A. (2000) Vascular Plant Species Richness in Alaskan Arctic Tundra: The Importance of Soil pH. Journal of Ecology, 88, 54-66. http://dx.doi.org/10.1046/j.1365-2745.2000.00426.x

[13] Eskelinen, A., Stark, S. and Männistö, M. (2009) Links between Plant Community Composition, Soil Organic Matter Quality and Microbial Communities in Contrasting Tundra Habitats. Oecologia, 161, 113-123. http://dx.doi.org/10.1007/s00442-009-1362-5

[14] Hobbie, S.E. (1992) Effects of Plant Species on Nutrient Cycling. Trends in Ecology \& Evolution, 7, 336-339. http://dx.doi.org/10.1016/0169-5347(92)90126-V

[15] Walker, D.A., Epstein, H.E., Gould, W.A., Kelley, A.M., Kade, A.N., Knudson, J.A., Krantz, W.B., Michaelson, G., Peterson, R.A., Ping, C.L., Raynolds, M.K., Romanovsky, V.E. and Shur, Y. (2004) Frost-Boil Ecosystems: Complex Interactions between Landforms, Soils, Vegetation and Climate. Permafrost and Periglacial Processes, 15, 171-188. http://dx.doi.org/10.1002/ppp.487

[16] Hobbie, S.E. (1996) Temperature and Plant Species Control over Litter Decomposition in Alaskan Tundra. Ecological Monographs, 66, 503-522. http://dx.doi.org/10.2307/2963492

[17] Chu, H. and Grogan, P. (2010) Soil Microbial Biomass, Nutrient Availability and Nitrogen Mineralization Potential among Vegetation-Types in a Low Arctic Tundra Landscape. Plant and Soil, 329, 411-420. http://dx.doi.org/10.1007/s11104-009-0167-y

[18] Walker, M.D., Walker, D.A. and Auerbach, N.A. (1994) Plant Communities of a Tussock Tundra Landscape in the Brooks Range Foothills, Alaska. Journal of Vegetation Science, 5, 843-866. http://dx.doi.org/10.2307/3236198

[19] Walker, D.A., Walker, M.D., Gould, W.A., Mercado, J., Auerbach, N.A., Maier, H.A. and Neufeld, G.P. (2010) Maps for Monitoring Long-Term Changes to Vegetation Structure and Composition, Toolik Lake, Alaska. In: Bryn, A., Dramstad, W. and Fjellstad, W., Eds., Mapping and Monitoring of Nordic Vegetation and Landscapes, Vol. 1, Norsk Institutt for Skog og Landskap, Ås, Norway, 121-123.

[20] Walker, D.A., Lederer, N.D. and Walker, M.D. (1987) Permanent Vegetation Plots: Site Factors, Soil Physical and Chemical Properties and Plant Species Cover. Department of Energy, R4D Program Data Report, Plant Ecology Laboratory, Institute of Arctic and Alpine Research, Boulder, National Snow and Ice Data Center. Identifier Number: ARCSS110.

[21] Walker, D.A. and Barry, N. (1991) Toolik Lake Permanent Vegetation Plots: Site Factors, Soil Physical and Chemical Properties, Plant Species Cover, Photographs, and Soil Descriptions. Data Report 48, Department of Energy R4D Program, Institute of Arctic and Alpine Research, University of Colorado, Boulder.

[22] Walker, D.A., Binnian, E., Evans, B.M., Lederer, N.D., Nordstrand, E. and Webber, P.J. (1989) Terrain, Vegetation and Landscape Evolution of the R4D Research Site, Brooks Range Foothills, Alaska. Holarctic Ecology, 12, 238-261.

[23] Keller, K., Blum, J.D. and Kling, G.W. (2007) Geochemistry of Soils and Streams on Surfaces of Varying Ages in Arctic Alaska. Arctic, Antarctic, and Alpine Research, 39, 84-98. http://dx.doi.org/10.1657/1523-0430(2007)39[84:GOSASO]2.0.CO;2

[24] Walker, D.A. and Maier, H.A. (2008) Vegetation in the Vicinity of the Toolik Field Station, Alaska. Biological Papers of the University of Alaska 28, Institute of Arctic Biology, Fairbanks.

[25] Wahrhaftig, C. (1965) Physiographic Divisions of Alaska U.S. Geological Survey Professional Paper 482. US Government Printing Office, Washington DC.

[26] Osterkamp, T.E., Petersen, J.K. and Collet, T.S. (1985) Permafrost Thicknesses in the Oliktok Point, Prudhoe Bay and Mikkelsen Bay Areas of Alaska. Cold Regions Science and Technology, 11, 99-105. http://dx.doi.org/10.1016/0165-232X(85)90010-2

[27] Hamilton, T.D. (2003) Glacial Geology of Toolik Lake and the Upper Kuparuk River Region. Biological Papers of the University of Alaska No. 26, University of Alaska Printing Services, Fairbanks.

[28] Hamilton, T.D. (2003) Surficial Geology of the Dalton Highway (Itkillik-Sagavanirktok Rivers) Area, Southern Arctic Foothills, Alaska. Alaska Division of Geological \& Geophysical Surveys Professional Report 121, Alaska, 32 p. 
[29] Cherry, J., Déry, S.J., Cheng, Y., Stieglitz, M., Jacobs, M.S. and Pan, F. (2014) Climate and Hydrometeorology of the Toolik Lake Region and the Kuparuk River Basin: Past, Present and Future. In: Hobbie, J.E. and Kling, G.W., Eds., Alaska's Changing Arctic: Ecological Consequences for Tundra, Streams and Lakes, Oxford University Press, New York, 31-60.

[30] Gould, W.A. and Mercado-Díaz, J.A. (2014) Decadal-Scale Changes of Vegetation from Long-Term Plots in Alaskan Tundra. In: Hobbie, J.E. and Kling, G.W., Eds., Alaska's Changing Arctic: Ecological Consequences for Tundra, Streams and Lakes, Vignette 5.5, Oxford University Press, New York, 130-131.

[31] Walker, D.A., Hamilton, T.D., Maier, H.A., Munger, C.A. and Raynolds, M.K. (2014) Glacial History and Long-Term Ecology in the Toolik Lake Region. In: Hobbie, J.E. and Kling, G.W., Eds., Alaska's Changing Arctic: Ecological Consequences for Tundra, Streams and Lakes, Oxford University Press, New York, 61-80.

[32] Shaver, G.R., Laundre, J.A., Bret-Harte, M.S., Chapin III, F.S., Mercado-Díaz, J.A., Giblin, A.E., Gough, L., Gould, W.A., Hobbie, S.E., Kling, G.W., Mack, M.C., Moore, J.C., Nadelhoffer, K., Rastetter, E.B. and Schimel, J.P. (2014) Terrestrial Ecosystems at Toolik Lake, Alaska. In: Hobbie, J.E. and Kling, G.W., Eds., Alaska's Changing Arctic: Ecological Consequences for Tundra, Streams and Lakes, Oxford University Press, New York, 90-142.

[33] Walker, D.A. (1996) GIS Data from the Alaska North Slope. National Snow and Ice Data Center. http://nsidc.org/data/arcss017.html

[34] Mercado-Díaz, J.A. (2011) Plant Community Responses of the Alaskan Arctic Tundra to Environmental and Experimental Changes in Climate. M.Sc. Thesis, University of Puerto Rico, Río Piedras Campus, San Juan.

[35] LECO Corp. (2006) LECO TruSpec CN Carbon/Nitrogen Determinator Instruction Manual. St. Joseph.

[36] LECO Corp. (2005) Carbon and Nitrogen in Soil and Sediment. Organic Application Note: TruSpec CN (Form No. 203-821-275). St. Joseph.

[37] LECO Corp. (2006) LECO TruSpec Add-On Module Sulfur Analyzer Instruction Manual. St. Joseph.

[38] LECO Corp. (2008) Sulfur in Cement, Fly Ash, Limestone, Soil and Ore. Organic Application Note: TruSpec S (Form No. 203-821-345). St. Joseph.

[39] Luh Huang, C.Y. and Schulte, E.E. (1985) Digestion of Plant Tissue for Analysis by ICP Emission Spectroscopy. Communications in Soil Science and Plant Analysis, 16, 943-958. http://dx.doi.org/10.1080/00103628509367657

[40] Wilde, S.A., Corey, R.B., Iyer, J.G. and Voight, G.K. (1979) Soil and Plant Analysis for Tree Culture. 5th Edition, Oxford \& IBH Publishing Co., New Delhi.

[41] McLean, E.O. (1982) Soil pH and Lime Requirement. In: Page, A.L., Miller, R.H. and Keeney, D.R., Eds., Methods of Soil Analysis, Part 2, Chemical and Microbiological Properties, Agronomy Monograph Number 9, Soil Science Society of America, Madison, 199-224.

[42] Michaelson, G.J., Ping, C.L. and Kimble, J.M. (1996) Carbon Storage and Distribution in Tundra Soils of Arctic Alaska, U.S.A. Arctic and Alpine Research, 28, 414-424. http://dx.doi.org/10.2307/1551852

[43] Ping, C.L., Michaelson, G.J., Loya, W.M., Chandler, R.J. and Malcolm, R.L. (1997) Characteristics of Soil Organic Matter in Arctic Ecosystems of Alaska. In: Lal, R., Kimble, J.M., Follet, R.F. and Stewart, B.A., Eds., Soil Processes and the Carbon Cycle, CRC Press LLC, Boca Raton, 157-167.

[44] Ping, C.L., Bockheim, J.G., Kimble, J.M., Michaelson, G.J. and Walker, D.A. (1998) Characteristics of Cryogenic Soils along a Latitudinal Transect in Arctic Alaska. Journal of Geophysical Research, 103, 28917-28928. http://dx.doi.org/10.1029/98JD02024

[45] Giblin, A.E., Nadelhoffer, K.J., Shaver, G.R., Laundre, J.A. and McKerrow, A.J. (1991) Biogeochemical Diversity along a Riverside Toposequence in Arctic Alaska. Ecological Monographs, 61, 415-435. http://dx.doi.org/10.2307/2937049

[46] Moore, P.D. (2008) Tundra. Infobase Publishing, New York.

[47] Giesler, R., Petersson, T. and Högberg, P. (2002) Phosphorus Limitation in Boreal Forests: Effects of Aluminum and Iron Accumulation in the Humus Layer. Ecosystems, 5, 300-314. http://dx.doi.org/10.1007/s10021-001-0073-5

[48] Birkeland, P.W., Burke, R.M. and Benedict, J.B. (1989) Pedogenic Gradients for Iron and Aluminum Accumulation and Phosphorus Depletion in Arctic and Alpine Soils as a Function of Time and Climate. Quaternary Research, 32, 193-204. http://dx.doi.org/10.1016/0033-5894(89)90075-6

[49] Ugolini, F.C., Stoner, M.G. and Marrett, D.J. (1987) Arctic Pedogenesis: 1. Evidence for Contemporary Podzolization. Soil Science, 144, 90-100. http://dx.doi.org/10.1097/00010694-198708000-00002

[50] Brady, N.C. and Weil, R.R. (2008) The Nature and Properties of Soils. Prentice-Hall Inc., New Jersey.

[51] Giesler, R., Andersson, T., Lövgren, L. and Persson, P. (2005) Phopshate Sorption in Aluminum and Iron-Rich Humus Soils. Soil Science Society of America Journal, 69, 77-86.

[52] Kang, J., Hesterberg, D. and Osmond, D.L. (2009) Soil Organic Matter Effects on Phosphorus Sorption: A Path Analy- 
sis. Soil Science Society of America Journal, 73, 360-366. http://dx.doi.org/10.2136/sssaj2008.0113

[53] Shaver, G.R. and Chapin III, F.S. (1986) Effect of Fertilizer on Production and Biomass of Tussock Tundra, Alaska, U.S.A. Arctic and Alpine Research, 18, 261-268. http://dx.doi.org/10.2307/1550883

[54] Shaver, G.R. and Chapin III, F.S. (1995) Long-Term Responses to Factorial, NPK Fertilizer Treatment by Alaskan Wet and Moist Tundra Sedge Species. Ecography, 18, 259-275. http://dx.doi.org/10.1111/j.1600-0587.1995.tb00129.x

[55] Jäggerbrand, A.K., Björk, R.G., Callaghan, T. and Seppelt, R.D. (2011) Effects of Climate Change on Tundra Bryophytes. In: Tuba, Z., Slack, N.G. and Stark, L.R., Eds., Bryophyte Ecology and Climate Change, Cambridge University Press, New York, 211-236.

[56] van der Welle, M.E.W., Vermeulen, P.J., Shaver, G.R. and Berendese, F. (2003) Factors Determining Plant Species Richness in Alaskan Arctic Tundra. Journal of Vegetation Science, 14, 711-720. http://dx.doi.org/10.1111/j.1654-1103.2003.tb02203.x

[57] Subberao, G.V., Ito, O., Berry, W.L. and Wheeler, R.M. (2003) Sodium-A Functional Plant Nutrient. Critical Reviews in Plant Sciences, 22, 391-416.

[58] Xu, W., Yuan, W., Dong, W., Xia, J., Liu, D. and Chen, Y. (2013) A Meta-Analysis of the Response of Soil Moisture to Experimental Warming. Environmental Research Letters, 8, 1-8. http://dx.doi.org/10.1088/1748-9326/8/4/044027

[59] Munroe, J.S. and Bockheim, J.G. (2001) Soil Development in Low-Arctic Tundra of the Northern Brooks Range, Alaska, U.S.A. Arctic, Antarctic and Alpine Research, 33, 78-87. http://dx.doi.org/10.2307/1552280

[60] Michaelson, G.J., Ping, C.L. and Kimble, J.M. (2001) Effects of Soil Morphological and Physical Properties on Estimation of Carbon Storage. In: Lal, R., Kimble, J.M., Follett, R.F. and Stewart, B.A., Eds., Assessment Methods for Soil Carbon, Lewis Publishers, Boca Raton, 339-347.

[61] Bockheim, J.G., Walker, D.A. and Everett, L.R. (1997) Soil Carbon Distribution in Non Acidic and Acidic Tundra of Arctic Alaska. In: Lal, R., Kimble, J.M., Follett, R.F. and Stewart, B.A., Eds., Soil Processes and the Carbon Cycle, CRC Press, Boca Raton, 143-155.

[62] Ping, C.L., Clark, M.H. and Swanson, D.K. (2004) Cryosols in Alaska. In: Kimble, J.M., Ed., Cryosols, Permafrost-Affected Soils, Springer-Verlag, New York, 71-94. 
Scientific Research Publishing (SCIRP) is one of the largest Open Access journal publishers. It is currently publishing more than 200 open access, online, peer-reviewed journals covering a wide range of academic disciplines. SCIRP serves the worldwide academic communities and contributes to the progress and application of science with its publication.

Other selected journals from SCIRP are listed as below. Submit your manuscript to us via either submit@scirp.org or Online Submission Portal.
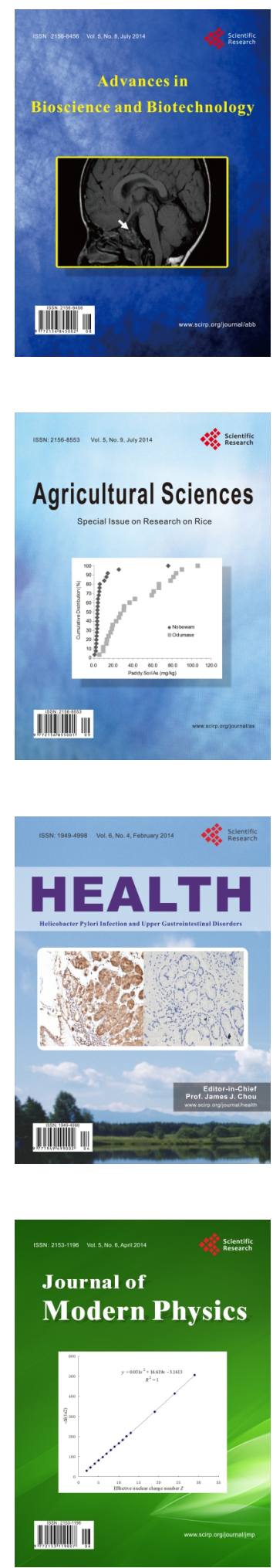
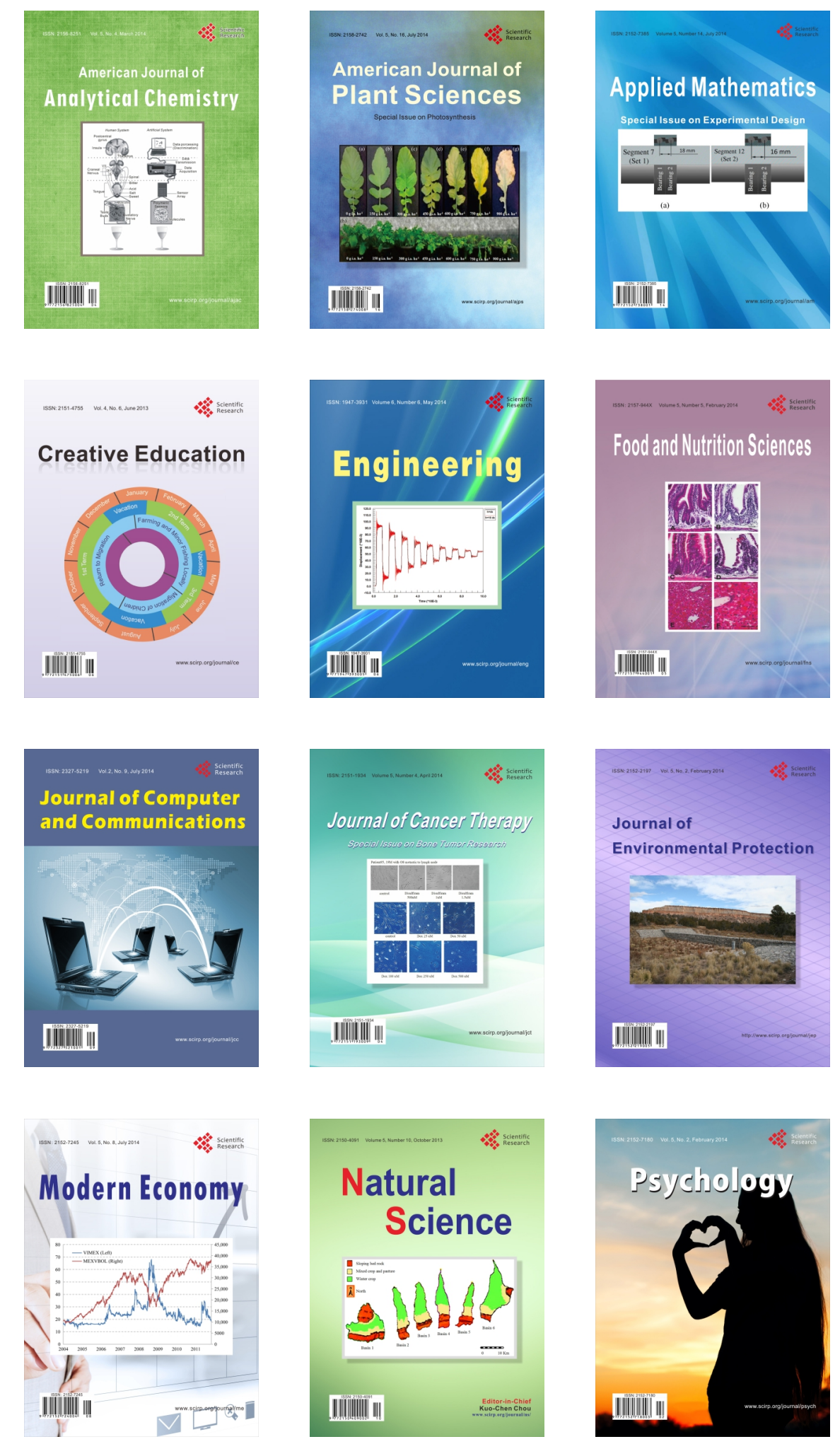